\title{
PENERAPAN PRINSIP MODIFIKASI PERILAKU UNTUK MENINGKATKAN KEMAMPUAN MENYIKAT GIGI PADA ANAK DENGAN DISABILITAS INTELEKTUAL BERAT
}

\author{
Catherina Kartika Hapsari, Fenny Hartiani \\ Fakultas Psikologi, Universitas Indonesia \\ Kampus Baru UI, Depok, Jawa Barat, Indonesia 16424 \\ catherinakartika@gmail.com
}

\begin{abstract}
Self-help skills are one of the skills needed to support one's life. Individuals with severe intellectual disability have difficulty to perform self-help tasks, such as dressing, bathing, and toothbrushing. In addition, individuals with intellectual disability usually have other health related problems. To prevent dental health problems among people with severe intellectual disability, it is necessary to prevent it by taking care of dental health. Toothbrushing is one of the most effective ways to prevent it and toothbrushing training are one of intervention that could help. This research applied behaviour modification total-task presentation in children with severe intellectual disability. This research is a quasi-experimental research using a single subject A-B-A design. The participants for this study were a 19-year-old female teenager with severe intellectual disability. This intervention was given as many as nine sessions in three weeks. The data were collected using interviews and observations to record the emergence of a series toothbrushing behavior. Data then analysed using visual inspections method. The results of this study indicate that the total task presentation intervention provides an improvement in the ability of brushing teeth. This improvement still needs to be supported by the carer's directions.
\end{abstract}

Keywords: intellectual disability; tooth brushing; behavior modification; total-task presentation

\begin{abstract}
Abstrak
Keterampilan menjaga kebersihan diri merupakan salah satu keterampilan yang dibutuhkankan untuk menunjang kehidupan individu. Individu dengan disabilitas intelektual berat memiliki karakteristik sulit melakukan tugastugas rawat diri sederhana, seperti berpakaian, mandi, dan sikat gigi. Selain itu individu dengan disabilitas intelektual juga memiliki resiko masalah kesehatan lain. Untuk menghindari permasalahan yang timbul pada kesehatan gigi orang dengan disabilitas intelektual maka diperlukan intervensi berupa pelatihan menyikat gigi. Penelitian ini menerapkan prinsip modifikasi perilaku total-task presentation pada anak dengan disabilitas intelektual berat untuk meningkatkan kemampuan menyikat gigi. Tujuan penelitian ini untuk mengetahui apakah penerapan total-task presentation dapat meningkatkan kemampuan kemampuan menyikat gigi pada anak dengan disabilitas intelektual berat. Penelitian ini merupakan penelitian kuasi-eksperimen menggunakan desain single subject $A-B$-A design. Pada penelitian ini partisipan adalah seorang remaja perempuan 19 tahun dengan disabilitas intelektual berat. Intervensi diberikan sebanyak sembilan sesi dalam tiga minggu. Penelitian ini menggunakan wawancara dan observasi untuk mencatat kemunculan rangkaian perilaku menyikat gigi. Data kemudian dianalisis menggunakan visual inspection untuk melihat keberhasilan penguasaan perilaku. Hasil dari peneltian ini menujukkan, intervensi total task presentation memberikan peningkatan kemampuan anak dalam hal menyikat gigi. Peningkatan kemampuan ini masih perlu didukung oleh arahan pengasuh.
\end{abstract}

Kata kunci: disabilitas intelektual; menyikat gigi; modifikasi perilaku; total-task presentation

\section{PENDAHULUAN}

Mengurus diri sendiri adalah salah satu keterampilan yang perlu dimiliki setiap orang. Melatih kemampuan kemandirian mengurus diri seperti makan, minum, mandi, menyikat gigi, buang air besar (BAB), buang air kecil (BAK), berpakaian, memakai sepatu, mengancingkan baju dan perawatan kesehatan tubuh pada anak dengan disabilitas sangatlah penting (Ardiç \& Cavkaytar, 2014). Penguasaan keterampilan mengurus diri 
merupakan tahapan pertama dari proses pencapaian kemandirian individu dan keterampilan tersebut akan terus digunakan sepanjang usia anak. Untuk orang dengan severe intellectual disability atau disabilitas intelektual berat, kemampuan mengurus diri sulit dilakukan. Orang dengan disabilitas intelektual berat memiliki keterbatasan pada kemampuan adaptif dan kognitif. Salah satu kemampuan adapatif yang sering terganggu pada orang dengan disabilitas intelektual berat adalah kemampuan mengurus diri secara independen (Cannella-Malone dkk., 2011). Ketidakmampuan ini disertai dengan perkembangan motorik anak yang tidak sesuai. Pada anak dengan disabilitas intelektual berat yang disertai dengan gangguan kesehatan down syndrome, keterlambatan perkembangan motorik adalah salah satu masalah yang sulit dihindari (Schott \& Holfelder, 2015). Kesulitan motorik yang dihadapi biasanya terkait dengan masalah adaptasi dengan lingkungan baru, koordinasi dan kontrol objek. Tanpa adanya pemberian intervensi dini, sulit untuk mengembangkan kemampuan motorik yang mampu dimiliki anak untuk mengurus keperluan dirinya sendiri. Hal itu membuat anak dengan disabilitas intelektual berat cukup dependen dengan pengasuh yang membantunya.

Salah satu keterampilan mengurus diri yang cukup penting adalah menyikat gigi. Menyikat gigi adalah salah satu cara untuk menjaga kebersihan, terutama terkait kesehatan mulut. Menjaga kebersihan secara independen sulit dilakukan oleh orang dengan disabilitas intelektual. Orang dengan disabilitas intelektual cenderung tidak mampu menjaga kesehatan mulut karena ketidakmampuannya melakukan pencegahan dini, seperti menyikat gigi, dengan tepat (Mae dkk., 2009). Keterampilan menyikat gigi adalah satu kemampuan adaptif individu yang perlu dimiliki oleh setiap orang untuk meningkatkan kualitas hidupnya. Penelitian mendapatkan bahwa anak dengan disabilitas intelektual kesulitan untuk menyikat giginya. Hal tersebut berhubungan dengan ketidaktahuan anak dengan pentingnya menjaga kesehatan mulut dan kemampuan motorik untuk menyikat gigi (Shin \& Saeed, 2013). Terkait dengan kesehatan mulut, orang dengan down syndrome dan disabilitas intelektual memiliki kemungkinan gangguan pada gusi gigi dan caries yang cukup tinggi (Mae dkk., 2009). Kebersihan mulut anak dengan disabilitas intelektual cenderung lebih buruk juga dipengaruhi obat, diet, dan kebersihan diri yang buruk (Lehl, 2013). Orangtua pun cenderung tidak memperhatikan kebutuhan pentingnya menjaga kebersihan mulut untuk meningkatkan kualitas hidup anak. Adanya kemampuan menjaga kesehatan mulut perlu diterapkan kepada anak sejak dini. Salah satu bentuk pencegahan yang dapat dilakukan dengan membiasakan perawatan mulut di rumah menggunakan obat kumur dan menyikat gigi dengan tepat dan teratur (Tufenk, 2012). Keterampilan untuk meyikat gigi memerlukan kemampuan psikomotor dan inhibitory control yang baik (Gligorović \& Buha Urović, 2014). Namun pada anak dengan disabilitas intelektual berat, dua kemampuan ini kurang berkembang dengan baik. Perkembangannya cenderung jauh di bawah rata-rata usianya.

Untuk orang dengan disabilitas intelektual berat, mempelajari keterampilan seperti ratarata anak seusianya merupakan tantangan yang sulit dan waktu yang lama. Biasanya anak dengan disabilitas intelektual berat akan diberikan latihan-latihan kemandirian untuk dapat mengurus dirinya sendiri (Ke \& Liu, 2012). Akan tetapi, anak dengan disabilitas intelektual cenderung memiliki kemajuan perkembangan lebih lambat daripada rata-rata anak seusianya. Hal tersebut dipengaruhi dengan kemampuan kapasitas anak, stimulasi atau bantuan dari lingkungan, gangguan kesehatan anak, dan dukungan lingkungan untuk membantu anak dalam menghadapi tantangan (Lewis \& Rudolph, 2014). Pada anak dengan disabilitas intelektual berat, hambatan komunikasi, hubungan interpersonal dengan caregiver, dan kemampuan mengurus diri menjadi faktor 
yang menghambat untuk mempelajari cara menjaga kesehatan mulut yang baik dan sehat (Lehl, 2013).

Latihan kemandirian yang efektif biasanya diberikan dengan intervensi langsung yang dapat dipraktikkan dengan memberikan bantuan berupa cues atau isyarat (CannellaMalone dkk., 2011). Dalam beberapa situasi, orang dengan disabilitas intelektual dapat dilatih ke dalam situasi yang lebih kondusif daripada situasi alami sehari-hari. Intervensi yang dilakukan harus kembali mempertimbangkan situasi atau keadaan orang tersebut. Bagi anak dengan disabilitas intelektual berat yang memiliki keterbatasan kemampuan kognitif, motorik, dan sosial, perlu adanya modifikasi metode latihan untuk membantu anak menyikat gigi.

Salah satu metode yang efektif untuk meningkatkan kemampuan anak adalah dengan menerapkan prinsip-prinsip modifikasi perilaku. Modifikasi perilaku merupakan suatu pendekatan behavioristik yang bertujuan untuk meningkatkan perilaku adaptif dan mengurangi perilaku maladaptif yang berlebihan dalam kehidupan sehari-hari (Kazdin, 2013). Teknik modifikasi perilaku sendiri merupakan aplikasi yang sistematik dari prinsip dan teknik belajar untuk meningkatkan perilaku individu yang tampak dan tidak tampak untuk meningkatkan keberfungsian individu sehari-hari (Martin \& Pear, 2015).

Ada berbagai teknik modifikasi perilaku yang biasa dilakukan untuk meningkatkan kemampuan menyikat gigi seperti, chaining, prompting, dan reinforcement. Chaining sendiri merupakan rangkaian perilaku yang berurutan dilakukan seseorang untuk menyelesaikan suatu tugas (Kazdin, 2013). Teknik chaining terdiri dari urutan stimulus dan respon yang terjadi berdekatan dan biasanya setelah akhir respon akan mendapatkan reinforcement, yaitu suatu objek atau kejadian yang diberikan sebagai upaya untuk meningkatkan kemungkinan perilaku tersebut muncul kembali (Kazdin,
2013; Martin \& Pear, 2015). Teknik tersebut terbukti efektif dalam program untuk mengajarkan berpakaian, grooming, bekerja, dan perilaku verbal bagi individu dengan gangguan perkembangan (Martin \& Pear, 2015). Prompting adalah pemberian stimulus yang diberikan untuk untuk meningkatkan kemungkinan munculnya perilaku yang diharapkan ada (Miltenberger, 2012). Prompt sendiri terdiri dari beberapa jenis yaitu physical prompt, gestural prompt, verbal prompt. Modifikasi perilaku yang juga sering diberikan adalah positive reinforcement. Positive reinforcement ditujukan untuk meningkatkan kemunculan perilaku yang diinginkan (Martin \& Pear, 2015).

Pelatihan modifikasi perilaku untuk melatih kemampuan sikat gigi sebelumnya, baru dicobakan pada anak dengan disabilitas intelektual tanpa melihat tingkat keparahannya (Pujiyasari, Hartini, \& Nurullita, 2014). Dari penelitian yang sama didapatkan bahwa anak-anak pun tidak dapat dilepas sendiri untuk mengerjakan, namun perlu adanya pengawasan yang mendukung. Penelitian tersebut menggunakan model orang langsung yang mencontohkan cara untuk menyikat gigi yang tepat. Penelitian berikutnya memberikan pelatihan menyikat gigi secara langsung kepada anak dengan disabilitas intelektual sedang untuk dapat meningkatkan kemampuan menyikat gigi (Agustiningsih \& Ahmad, 2016). Namun kedua penelitian ini kurang menjelaskan detil analisis tugas menyikat gigi untuk anak dengan disabilitas intelektual berat. Penelitian terbaru dilakukan dengan menerapkan totaltask presentation untuk anak dengan disabilitas intelektual sedang (Kusharyani \& Kurnianingrum, 2016). Pada penelitian ini peneliti melakukan task analysis, pengambilan data baseline, pelaksanaan intervensi total-task presentation dengan bantuan prompt dan reinforcement untuk memperkuat kemunculan perilaku. Namun demikian penerapan intervensi ini hanya diterapkan kepada anak dengan disabilitas intelektual sedang. Ada beberapa perbedaan fungsi adaptif orang dengan disabilitas 
intelektual dengan keparahan moderate (sedang) dan severe (berat), seperti kemampuan mengurus diri yang lebih dependen, kemampuan pemahaman bahasa reseptif serta ekspresif yang terbatas, dan pemahaman konseptual yang lebih terbatas (American Psychiatric Association, 2013). Mempertimbangkan kemampuan anak dengan disabilitas intelektual berat, diperlukan intervensi yang membantu anak untuk menyikat gigi mandiri yang sederhana dan mengajarkan cues dari pengasuh yang membantunya. Adanya pelatihan bagi pengasuh untuk membantu anak dengan disabilitas intelektual dapat meningkatkan kemampuan anak menyikat gigi dan kesehatan gigi serta mulut (Fickert \& Ross, 2012). Untuk itu kemampuan pengasuh memberikan arahan untuk menyikat gigi perlu diberikan secara spesifik. Intervensi modifikasi perilaku merupakan salah satu intervensi yang dapat dilakukan untuk meningkatkan perilaku adapatif (Kazdin, 2013). Diharapkan dengan menerapkan intervensi ini dapat meningkatkan kemampuan untuk menyikat gigi pada anak dengan gangguan disabilitas intelektual berat. Tujuan dari penelitian ini adalah untuk mengetahui apakah program modifikasi perilaku total-task presentation efektif untuk meningkatkan kemampuan menyikat gigi pada anak dengan disabilitas intelektual berat.

\section{METODE}

Desain penelitian ini menggunakan single subject desain A-B-A (Comer \& Kendall, 2013). Metode ini mengamati dan membandingkan perilaku partisipan sebelum, selama sesi pemberian intervensi dan setelah intervensi. Rancangan intervensi ini diberikan untuk meningkatkan keterampilan menyikat gigi bagi anak dengan disabilitas intelektual berat.

Partisipan pada penelitian ini adalah $\mathrm{N}$, anak perempuan berusia 19 tahun 4 bulan. N merupakan salah satu klien yang datang ke salah satu Puskesmas di Depok dengan riwayat perkembangan yang terlambat.
Orangtua mengeluhkan kemampuan $\mathrm{N}$ yang belum bisa bicara dan masih perlu bantuan dalam mengurus diri, seperti buang air dan mandi. Ia baru bisa merangkak dan berdiri dengan pegangan pada usia 2 tahun 6 bulan. Ketika berusia 3 tahun, dokter mengatakan $\mathrm{N}$ memiliki down syndrome berdasarkan pemeriksaan fisik. Dokter pun tidak menjelaskan penanganan yang diperlukan orangtua untuk mengasuh anak. Hasil pemeriksaan juga menunjukkan gangguan lain terkait fungsi kognitif dan adaptif seharihari. Berdasarkan perilaku dan gejala yang muncul, $\mathrm{N}$ didiagnosis dengan disabilitas intelektual berat.

Salah satu keluhan dari orangtua adalah perilaku $\mathrm{N}$ yang sulit mengurus kebersihan dirinya. $\mathrm{N}$ kurang mampu mengurus diri sendiri terutama $\mathrm{N}$ tidak mau menyikat gigi sendiri walaupun sudah diberikan pasta gigi di atas sikat gigi. Pada penelitian ini, peneliti menggunakan intervensi modifikasi perilaku. Prosedur penelitian akan diawali dengan melakukan task analysis yaitu mengidentifikasi perilaku yang dibutuhkan secara spesifik untuk melakukan suatu tindakan, kemudian melakukan pengumpulan data baseline atau observasi awal perilaku yang ingin dicapai sebelum intervensi, lalu pemberian intervensi, dan pengukuran perilaku setelah diberikan intervensi. Teknik modifikasi perilaku yang dilakukan pada penelitian ini adalah teknik chaining. Salah satu metode chaining yang dilakukan untuk meningkatkan keterampilan menyikat gigi pada anak dengan disabilitas intelektual yaitu total-task presentation.

Total-task presentation merupakan metode membentuk perilaku yang mendorong individu mencoba semua tahap dari awal sampai akhir rantai pada masing-masing percobaan hingga semua rangkaian perilaku dikuasai (Martin \& Pear, 2015; Miltenberger, 2012). Metode total task presentation akan menghasilkan peningkatan perilaku yang lebih cepat terlebih jika anak sudah mengetahui beberapa tahapan, seperti menyikat bagian depan gigi (dari serangkaian 
proses yang akan dijalani). Untuk diberikan prompt pada setiap tahapan yang meningkatkan kemungkinan seseorang agar tidak muncul. Format total-task presentation lebih menunjukkan respon yang diinginkan, tersaji dalam Gambar 1.

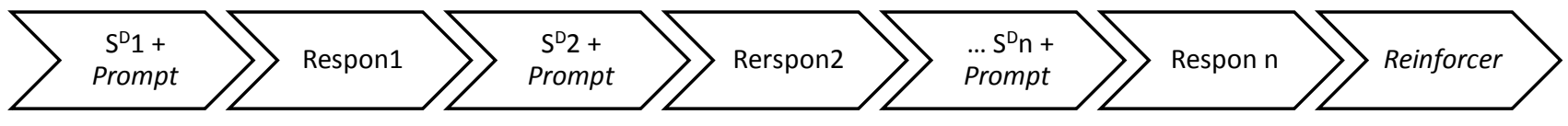

Gambar 1. Total-Task Presentation

Sebelum intervensi dimulai, peneliti komponen respon. Adapun hasil task analysis melakukan proses task analysis yaitu menyikat gigi dapat dilihat pada Tabel 1. menguraikan perilaku menyikat gigi menjadi

Tabel 1.

Hasil Task Analysis Menyikat Gigi

\begin{tabular}{|c|c|c|}
\hline No & Discriminative stimulus & Responses \\
\hline 1 & $\begin{array}{l}\text { Diberikan sikat gigi dengan pasta gigi yang } \\
\text { sudah dibasahi }\end{array}$ & $\begin{array}{l}\text { Mengambil sikat gigi dengan pasta gigi } \\
\text { yang sudah dibasahi }\end{array}$ \\
\hline 2 & Memegang sikat gigi dengan pasta gigi & $\begin{array}{l}\text { Menyikat seluruh gigi bagian luar bawah } \\
\text { sebelah kiri }\end{array}$ \\
\hline 3 & $\begin{array}{l}\text { Sudah menyikat seluruh gigi bagian luar } \\
\text { bawah sebelah kiri }\end{array}$ & $\begin{array}{l}\text { Menyikat seluruh gigi bagian luar bawah } \\
\text { sebelah kanan }\end{array}$ \\
\hline 4 & $\begin{array}{l}\text { Sudah menyikat seluruh gigi bagian luar } \\
\text { bawah sebelah kanan }\end{array}$ & $\begin{array}{l}\text { Menyikat seluruh gigi bagian luar atas } \\
\text { sebelah kiri }\end{array}$ \\
\hline 5 & $\begin{array}{l}\text { Sudah menyikat seluruh gigi bagian luar atas } \\
\text { sebelah kiri }\end{array}$ & $\begin{array}{l}\text { Menyikat seluruh gigi bagian luar atas } \\
\text { sebelah kanan }\end{array}$ \\
\hline 6 & $\begin{array}{l}\text { Sudah menyikat seluruh gigi bagian luar atas } \\
\text { sebelah kanan }\end{array}$ & $\begin{array}{l}\text { Menyikat seluruh gigi bagian permukaan } \\
\text { bawah sebelah kiri }\end{array}$ \\
\hline 7 & $\begin{array}{l}\text { Sudah menyikat seluruh gigi bagian } \\
\text { permukaan bawah sebelah kiri }\end{array}$ & $\begin{array}{l}\text { Menyikat seluruh gigi bagian permukaan } \\
\text { bawah sebelah kanan }\end{array}$ \\
\hline 8 & $\begin{array}{l}\text { Sudah menyikat seluruh bagian permukaan } \\
\text { bawah sebelah kanan }\end{array}$ & $\begin{array}{l}\text { Menyikat seluruh gigi bagian permukaan atas } \\
\text { sebelah kiri }\end{array}$ \\
\hline 9 & $\begin{array}{l}\text { Sudah menyikat seluruh gigi bagian } \\
\text { permukaan atas sebelah kiri }\end{array}$ & $\begin{array}{l}\text { Menyikat seluruh gigi bagian permukaan atas } \\
\text { sebelah kanan }\end{array}$ \\
\hline 10 & $\begin{array}{l}\text { Sudah menyikat seluruh gigi bagian } \\
\text { permukaan atas sebelah kanan }\end{array}$ & Menyikat bagian lidah \\
\hline 11 & Sudah menyikat bagian lidah & kat gigi kepada $\mathrm{p}$ \\
\hline 12 & Diberikan gayung yang sudah diisi air & Mengambil gayung yang sudah diisi air \\
\hline 13 & Meminum air dari gayung & Berkumur \\
\hline 14 & Selesai berkumur & Membuang air setelah berkumur dari mulut \\
\hline
\end{tabular}

Peneliti kemudian melakukan pengukuran awal atau baseline. Peneliti meminta partisipan untuk melakukan kegiatan menyikat gigi. Di tahap baseline ini peneliti tidak memberikan prompt atau reinforcer apapun saat anak melakukan kegiatan menyikat gigi. Pada baseline, peneliti akan melihat langkah-langkah menyikat gigi yang sudah mampu dilakukan dan dikuasai partisipan pada setiap percobaan.
Pengambilan data baseline menggunakan metode multiple-opportunities. Metode ini menurut Miltenberger (2012) bertujuan untuk menilai kemampuan subjek dalam melakukan setiap tahapan dalam sebuah rangkaian perilaku. Pada tahapan ini, peneliti melakukan observasi rangkaian perilaku yang sudah dapat dilakukan oleh N. Perilaku dicatat pada lebar pantau perilaku berdasarkan task analysis. Pada penelitian ini baseline 
dilakukan selama dua hari dengan percobaan sebanyak tiga kali setiap harinya.

Program disusun untuk membantu N mengenal urutan langkah-langkah yang diharapkan ketika menyikat gigi. Sesi dirancang dengan most to least prompting, di mana prompt yang diberikan merupakan prompt paling intrusif untuk partisipan untuk menghasilkan perilaku yang diharapkan dan ketika sudah muncul mengurangi tingkat intrusif prompt (Miltenberger, 2012). Adapun urutan prompt paling intrusif untuk partisipan adalah physical prompts, yaitu mengarahkan partisipan langkah-langkah menyikat gigi secara langsung dengan menggerakkan tangan partisipan untuk menyikat gigi bagian tertentu; gesture prompts, yaitu mengarahkan partisipan untuk menyikat gigi dengan memberikan gerakan atau arahan, seperti menunjuk pipi atau gigi untuk memberitahu bagian gigi yang harus disikat; dan verbal prompts, yaitu prompt diberikan dengan cara memberikan instruksi secara lisan seperti "pindah". Mempertimbangkan kemampuan partisipan, program intervensi akan diakhiri ketika partisipan sudah mampu melaksanakan setiap langkah pada satu sesi minimal dengan gesture prompt.

Pada saat pelaksanaan program, di setiap sesi nantinya akan dilakukan tiga percobaan. Sesi dilaksanakan selama dua jam, menggunakan jeda 30 menit tiap percobaan. Pada setiap percobaan, peneliti mencatat perilaku yang muncul berdasarkan task analysis dan prompt yang digunakan untuk setiap stimulus menghasilkan respon pada lembar pantau perilaku. Ketika partisipan menyelesaikan satu rangkaian chaining menyikat gigi, partisipan akan diberikan positive reinforcement. Pemberian positive reinforcement ditujukan untuk meningkatkan kemunculan perilaku yang diinginkan (Martin \& Pear, 2015). Pemilihan reinforcement disesuaikan dengan pilihan anak dan diperoleh berdasarkan wawancara dengan orang tua serta observasi perilaku partisipan tentang hal-hal yang disukai. Melalui wawancara dengan orang tua, peneliti dan orang tua memilih reinforcement berupa aktivitas (mewarnai) dan makanan kecil. Setiap sesi dinyatakan berhasil bila partisipan mampu melaksanakan tiga percobaan yang diberikan. Generalisasi program dilakukan pada akhir program, di mana orangtua mencoba memberikan prompt kepada partisipan pada setiap percobaan. Sesi intervensi dihentikan ketika partisipan sudah mampu melakukan setiap perilaku rangkaian menyikat gigi hanya dengan pemberian gesture prompt atau tanpa pemberian prompt.

Setelah pemberian intervensi dilakukan sesi follow up yang sama sesuai dengan prosedur pengambilan data baseline. Sesi follow up dilakukan dua minggu setelah pemberian intervensi terakhir. Program dinyatakan berhasil ketika pada sesi follow up, $\mathrm{N}$ dapat mempertahankan kemunculan perilaku menyikat gigi dengan tepat dengan minimal bantuan gesture prompt. Data observasi yang didapat dari lembar pantau perilaku pada saat baseline, pelaksanaan program, dan follow up kemudian dianalisis dengan metode visual inspection yaitu dengan membandingkan hasil ketika tidak diberikan intervensi dan saat diberikan intervensi (Kazdin, 2011). Untuk analisis data, peneliti akan membandingkan rangkaian perilaku yang sudah dikuasai dari saat sebelum diberikan intervensi, saat intervensi, dan follow up.

Setelah orangtua mengetahui secara rinci program yang dijalankan, orang tua menandatangani parental consent sebagai bukti persetujuan orangtua mewakili anak untuk berpartisipasi pada intervensi yang diberikan. Peneliti juga menyampaikan bahwa setiap sesi dilaksanakan oleh peneliti dengan pendampingan orangtua atau kakak.

\section{HASIL DAN PEMBAHASAN}

Berdasarkan langkah yang bisa dilakukan oleh partisipan (minimal dengan pemberian gesture prompt), partisipan menunjukkan perkembangan yang positif untuk menyikat gigi. Hal ini juga mendukung penelitian sebelum bahwa intervensi perilaku adalah 
metode yang tepat untuk melatih kemampuan anak dalam menyikat gigi (Kusharyani \& Kurnianingrum, 2016; Pujiyasari dkk., 2014). Bagi remaja dengan keterbatasan seperti $\mathrm{N}$ perkembangan kemandirian membutuhkan bantuan atau dukungan orang lain serta waktu yang lebih lama daripada remaja lain (Harris, 2006). Peningkatan dapat dilihat pada Gambar 2.

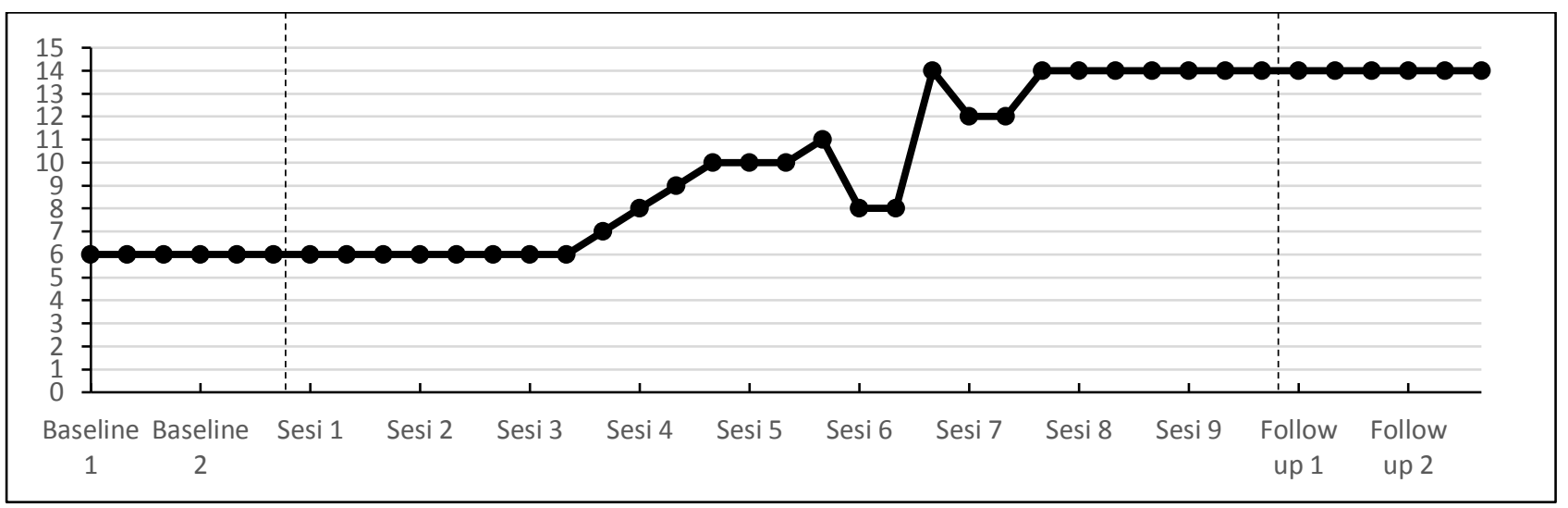

Gambar 2. Langkah yang Sudah Bisa Dilakukan (Minimal dengan Gesture Prompt)

Dari pelaksanaan terlihat adanya peningkatan mulai terlihat pada sesi 3 setelah adanya latihan 6 kali. Hal ini menunjukkan adanya kesulitan pada awal program untuk partisipan mengikuti instuksi dalam menyikat gigi. Partisipan membutuhkan waktu untuk menyesuaikan diri dengan urutan langkah menyikat gigi dan kehadiran peneliti yang mengarahkan.

Partisipan mampu mengikuti instruksi sederhana yang diberikan oleh pendamping dan ibu. Adanya penurunan langkah yang bisa dilakukan partisipan terjadi karena adanya jeda waktu yang cukup lama (7 hari) antara sesi 5 dan 6. Hal itu karena kondisi mata partisipan yang terkena infeksi sehingga membutuhkan istirahat dan perawatan.
Adanya jeda waktu yang lama ini, mungkin memengaruhi latihan yang membuat partisipan dapat lupa. Selain itu terjadi perubahan waktu latihan setelah sesi 5 karena perubahan waktu tidur. Gangguan tidur merupakan salah satu hal yang juga menjadi masalah bagi orang dengan gangguan perkembangan (Didden, Korzilius, Van Aperlo, Van Overloop, \& De Vries, 2002; Esbensen \& Schwichtenberg, 2016). Adanya gangguan tidur ini meningkatkan kemunculan perilaku mudah marah dan hiperaktif. Hal ini menghambat intervensi karena partisipan tidak mau mengikuti arahan peneliti.

Pemberian physical prompt pun sudah berkurang. Walaupun masih diberikan beberapa prompt verbal dan fisik. Jumlah prompt yang diberikan dapat dilihat pada Gambar 3. 


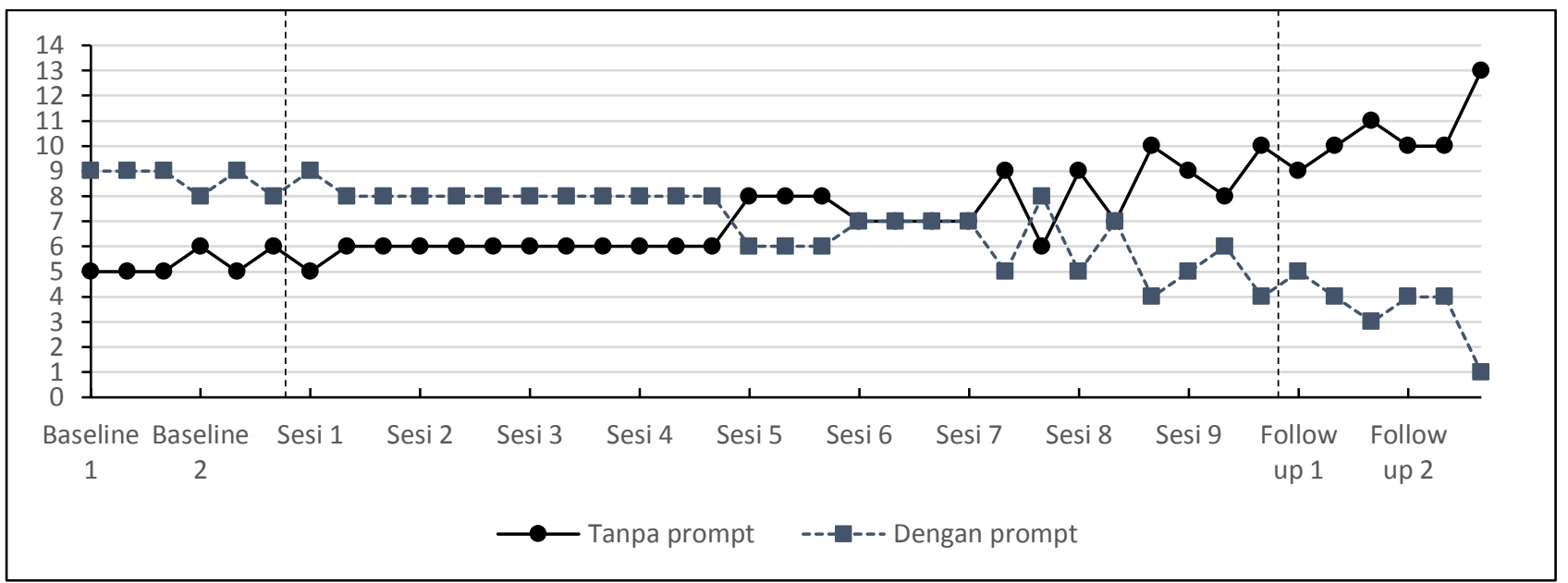

Gambar 3. Langkah yang Diberikan Prompt dan Tanpa Prompt

Dari hasil yang didapat, terlihat adanya peningkatan dari jumlah langkah yang dikuasai anak tanpa pemberian prompt. Namun dari beberapa pemberian prompt untuk menyelesaikan sikat gigi, masih ada beberapa langkah yang kurang konsisten. Pemberian prompt kurang konsisten antara gesture prompt, verbal prompt, dan physical prompt dapat dilihat pada Gambar 4.

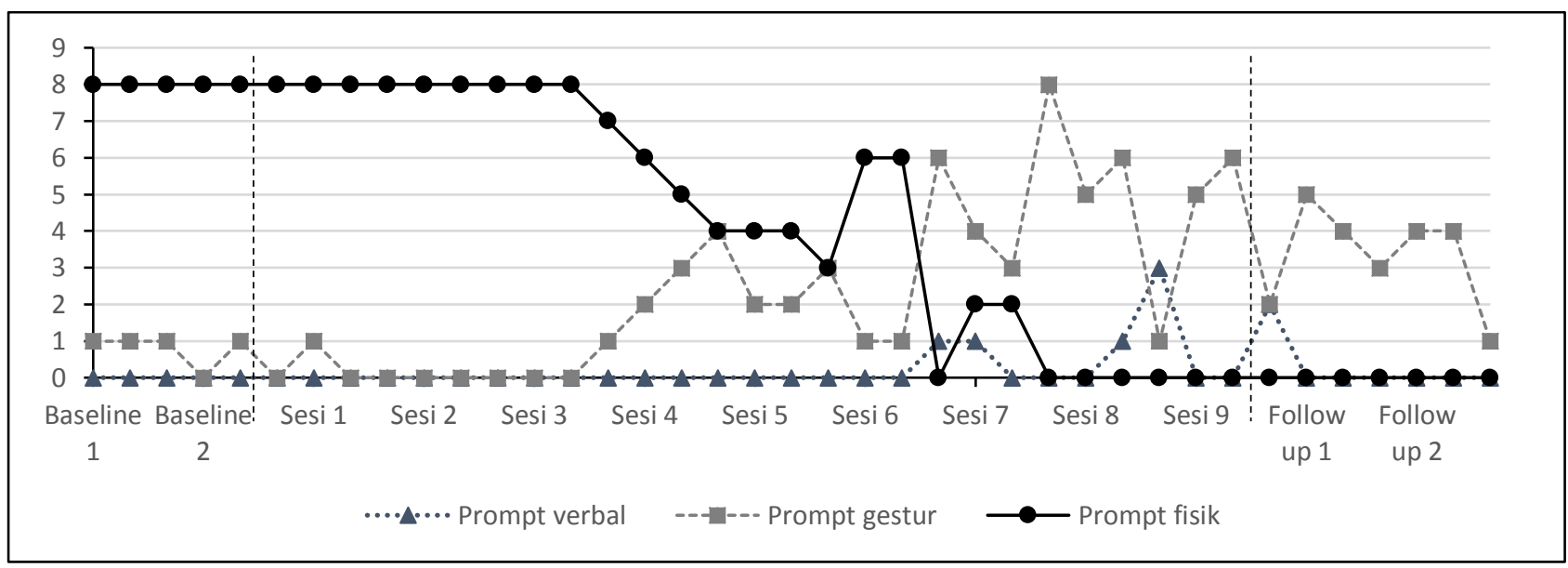

Gambar 4. Pemberian Gesture Prompt, Verbal Prompt, dan Physical Prompt

Dari hasil ini, terlihat adanya penurunan pemberian prompt fisik secara bertahap. Hal ini menunjukkan adanya pembelajaran yang didapatkan anak ketika menyelesaikan tugas secara langsung. Hal itu sama seperti penelitian sebelumnya yang mendapatkan intervensi berbasis modifikasi perilaku akan menunjukkan pengurangan prompt (Brown, 2012; Tufenk, 2012). Dari kedua penelitian tersebut juga dicobakan beberapa teknik intervensi perilaku lain yang juga cukup membantu, seperti video modelling. Bagi anak dengan disabilitas intelektual berat, kehadiran pengasuh atau orang lain dibutuhkan untuk membantu kebutuhan sehari-harinya (Ke \& Liu, 2012). Dengan latihan, kegiatan sehari-hari dapat anak kuasai, namun tetap masih bergantung dengan orang lain. Seperti halnya untuk melatih menyikat gigi. Sebagian anak dengan disabilitas intelektual tetap membutuhkan arahan dari pengasuh lain (Pujiyasari dkk., 2014). Pada anak dengan disabilitas intelektual, pengajaran suatu keterampilan memerlukan waktu yang cukup lama dan konsisten (Cannella-Malone dkk., 2011; Cullen \& Alber-Morgan, 2015). Keberadaan prompt meningkatkan kemunculan perilaku 
yang diharapkan untuk anak menguasai keterampilan yang diajarkan.

Namun demikian, pemberian gesture prompt dan verbal prompt kurang konsisten. Hal tersebut dipengaruhi dengan keadaan partisipan yang memiliki disabilitas intelektual. Pada anak dengan disabilitas intelektual, kemampuan kognitif menjadi salah satu hambatan. Pada orang dengan disabilitas intelektual, kemungkinan besar ditemukan adanya hambatan yang mengganggu daya ingat jangka panjang (Vicari, Costanzo, \& Menghini, 2016). Ketidakmampuan tersebut memengaruhi daya ingat dan juga pribadi partisipan yang cenderung hanya mau mengikuti keinginannya sendiri serta menghiraukan arahan orang lain.

Perkembangan remaja sangat bergantung dari motivasi orang itu sendiri dan lingkungan sekitar yang mendukung. Perkembangan anak yang memiliki motivasi untuk menguasai suatu keterampilan mendorong anak untuk dapat menguasai keterampilan tersebut (Cuskelly \& Gilmore, 2014). Ditemukan motivasi untuk anak dengan disabilitas intelektual cenderung defisit dibandingkan anak normal. Adanya pemberian reinforcement dan kehadiran keluarga mendorong perkembangan anak yang semula kurang dapat meningkat. Hal ini terlihat selama pelaksanaan yang awalnya sulit memunculkan perilaku menyikat gigi karena kurang konsistennya kehadiran pendamping selama kegiatan menyikat gigi. Dengan adanya reinforcement setelah kegiatan dan kehadiran anggota keluarga meningkatkan kemunculan perilaku menyikat gigi yang tepat.

Setelah melaksanakan program pelatihan ini, terdapat beberapa hal yang perlu diperhatikan yang dapat memengaruhi keberhasilan pelaksanaan program. Pertama terkait dengan penentuan waktu pelaksanaan sesi. Sebaiknya pelatihan dilaksanakan mempertimbangkan waktu tidur. Pada penelitian sebelumnya, didapatkan bahwa waktu tidur yang singkat pada individu dengan disabilitas intelektual berhubungan dengan sikap yang tidak kooperatif di siang hari atau setelah bangun (Surtees, Oliver, Jones, Evans, \& Richards, 2018). Hal itu memengaruhi sikap pada saat latihan. Pada waktu tersebut, partisipan baru bangun tidur dan sudah makan sehingga lebih kooperatif dalam menjalankan sesi. Partisipan pun lebih menyimak ketika latihan dilakukan siang hari. Orangtua memerlukan strategi untuk memperbaiki waktu tidur anak, seperti dengan membuat rutinitas membersihkan diri sebelum tidur (Ageranioti-Bélanger dkk., 2012). Kedua terkait dengan peran serta orangtua di awal program. Pada pelaksanaan pelatihan sebaiknya orangtua atau pengasuh hadir saat latihan. Hal ini membantu untuk transisi dari pemberi intervensi ke pengasuh. Dengan adanya perbaikan hal ini, diharapkan program yang dilaksanakan akan lebih singkat dan konsisten.

Peneliti juga menyadari peneliti memiliki keterbatasan. Penelitian ini merupakan penelitian single-subject. Hal ini membuat kemanfaatan penelitian ini terbatas pada partisipan dengan karakteristik disabilitas intelektual berat seperti N. Selain itu dampak dari intervensi tidak dapat sepenuhnya dapat dipastikan hanya karena adanya pemberian intervensi, seperti pengaruh dari kehadiran peneliti sebagai pemberi instruksi. Namun demikian perlu adanya penelitian terkait pengembangan kemandirian anak disabilitas intelektual. Adapun untuk pengembangan penelitian ke depan, sebaiknya dilakukan penilaian oleh observer kedua yang mencatat perilaku partisipan dalam sesi intervensi. Hal ini dapat meningkatkan validitas dan reliabilitas penelitian. Selain itu perlu adanya kontrol terhadap pelaksanaan intervensi seperti waktu pelaksanaan dan jeda waktu sesi yang lebih konsisten.

\section{SIMPULAN}

Pelaksanaan program intervensi meningkatkan kemampuan menyikat gigi dengan metode total-task presentation pada anak dengan disabilitas intelektual berat dapat 
dikatakan berhasil. Sebelum melaksanakan pelatihan, kemunculan perilaku menyikat gigi sulit diarahkan. Dari hasil baseline diketahui kemampuan untuk melakukan setiap tahap menyikat gigi yang sudah ditentukan masih defisit. Setelah 9 kali sesi pelatihan dengan jumlah latihan sebanyak tiga kali per sesi, kemampuan partisipan meningkat dan ia dapat melakukan gerakan dengan konsisten serta arah gerakan yang tepat.

\section{DAFTAR PUSTAKA}

Ageranioti-Bélanger, S., Brunet, S., D’Anjou, G., Tellier, G., Boivin, J., \& Gauthier, M. (2012). Behaviour disorders in children with an intellectual disability. Paediatrics \& Child Health, 17(2), 8488. https://doi.org/10.1093/pch/17.2.84.

Agustiningsih, A. A., \& Ahmad, I. (2016). Pelatihan menggosok gigi untuk meningkatkan kemampuan bina diri anak tunagrahita sedang di SLB dharma wanita lebo sidoarjo. Jurnal Pendidikan Khusus, 9(1), 1-10.

American Psychiatric Association. (2013). Diagnostic and statistical manual of mental disorders (5th ed.). Arlington: American Psychiatric Association. https://doi.org/10.1176/appi.books.9780 890425596.744053 .

Ardiç, A., \& Cavkaytar, A. (2014). Effectiveness of the modified intensive toilet training method on teaching toilet skills to children with autism. Education and Training in Autism and Developmental Disabilities, 49(2), 263276.

Brown, R. A. (2012). Training and assessment of toothbrushing skills among children with special needs. (Thesis). University of South Florida.

Cannella-Malone, H. I., Fleming, C., Chung, Y. C., Wheeler, G. M., Basbagill, A. R., \& Singh, A. H. (2011). Teaching daily living skills to seven individuals with severe intellectual disabilities: A comparison of video prompting to video modeling. Journal of Positive Behavior Interventions, 13(3), 144-153. https://doi.org/10.1177/1098300710366 593.

Comer, J. S., \& Kendall, P. C. (Eds.). (2013). The Oxford handbook of research strategies for clinical psychology. New York: Oxford University Press.

Cullen, J. M., \& Alber-Morgan, S. R. (2015). echnology mediated self-prompting of daily living skills for adolescents and adults with disabilities: A review of the literature. Autism and Developmental Disabilities, 50(501), 43-55.

Cuskelly, M., \& Gilmore, L. (2014). Motivation in children with intellectual disabilities. Research and Practice in Intellectual and Developmental Disabilities, 1(1), 51-59. https://doi.org/10.1080/23297018.2014. 906051.

Didden, R., Korzilius, H., Van Aperlo, B., Van Overloop, C., \& De Vries, M. (2002). Sleep problems and daytime problem behaviours in children with intellectual disability. Journal of Intellectual Disability Research, 46(7), 537-547.

https://doi.org/10.1046/j.13652788.200

2.00404.x

Esbensen, A. J., \& Schwichtenberg, A. J. (2016). Sleep in neurodevelopmental disorders. International Review of Research in Developmental Disabilities, 51,153-191.

https://doi.org/10.1016/bs.irrdd.2016.07 .005

Fickert, N. A., \& Ross, D. (2012). Effectiveness of a caregiver education program on providing oral care to individuals with intellectual and developmental disabilities. Intellectual and Developmental Disabilities, 50(3), 
219-232. https://doi.org/10.1352/19349556-50.3.219

Gligorović, M., \& Buha Urović, N. (2014). Inhibitory control and adaptive behaviour in children with mild intellectual disability. Journal of Intellectual Disability Research, 58(3), 233-242.

https://doi.org/10.1111/jir.12000

Harris, J. C. (2006). Intellectual disability: Understanding its development, causes, classification, evaluation, and treatment. New York: Oxford University Press. https://doi.org/10.1057/9781137025586

Kazdin, A. E. (2011). Single-case research designs: Methods for clinical and applied settings. animal genetics (2nd ed., Vol. 39). New York: Oxford University Press.

Kazdin, A. E. (2013). Behavior modification in applied settings (7th ed.). Illinois: Waveland Press.

Ke, X., \& Liu, J. (2012). Intellectual disability. In J. M. Rey (Ed.), IACAPAP Textbook of Child and Adolescent Mental Health (hal. 1-25). Geneva: International Association for Child and Adolescent Psychiatry and Allied Professions.

Kusharyani, F., \& Kurnianingrum, W. (2016). Penerapan total-task presentation dalam meningkatkan kemampuan menggosok gigi pada anak moderate intellectual disability. Jurnal Muara Ilmu Sosial, Humaniora, dan Seni, 1(2), 32-40.

Lehl, G. (2013). Issues in the dental care of children with intellectual disability. Open Access Scientific Reports, 2(3), $1-$ 4.

https://doi.org/10.4172/scientificreports. 695

Lewis, M., \& Rudolph, K. D. (Eds.). (2014). Handbook of developmental psychopathology. New York: Springer Science + Business Media.

Mae, C., Fenton, S. J., Lyons, R., Miller, C., Perlman, S. P., \& Tesini, D. (2009). Practical oral care for people with intellectual disability, National Institute of Dental and Craniofacial Research. Bethesda, MD: NIH Publication.

Martin, G., \& Pear, J. (2015). Behavior modification: What it is and how to do it (10th ed.). New Jersey: Pearson.

Miltenberger, R. G. (2012). Behavior modification: Principles and procedures (5th ed.). Belmont: Wadsworth. https://doi.org/10.1177/0145445503255 600

Pujiyasari, S., Hartini, S., \& Nurullita, U. (2014). Pengaruh metode latihan menggosok gigi dengan kemandirian menggosok gigi anak retardasi mental usia sekolah. Jurnal Keperawatan dan Kebidanan, 1, 1-11. https://doi.org/10.1017/CBO978110741 5324.004

Schott, N., \& Holfelder, B. (2015). Relationship between motor skill competency and executive function in children with Down's syndrome. Journal of Intellectual Disability Research, 59(9), 860-872. https://doi.org/10.1111/jir.12189

Shin, C. J., \& Saeed, S. (2013). Toothbrushing barriers for people with developmental disabilities: A pilot study. Special Care in Dentistry, 33(6), 269-274.

https://doi.org/10.1111/scd.12024

Surtees, A., Oliver, C., Jones, C., Evans, D., \& Richards, C. (2018). Sleep duration and sleep quality in people with and without intellectual disability: A metaanalysis. Sleep Medicine Reviews, 40. https://doi.org/10.1016/j.smrv.2017.11. 003 
Tufenk, T. (2012). The effect of behavioral skills training for dental hygiene students on treatment of special needs patients during dental care procedures. (Thesis). Southern Illinois University Carbondale.
Vicari, S., Costanzo, F., \& Menghini, D. (2016). Memory and learning in intellectual disability. International Review of Research in Developmental Disabilities, 50, 119-148. https://doi.org/10.1016/bs.irrdd.2016.05 .003 